\title{
VARIABILITY AND SPATIAL CORRELATION OF AGGREGATES AND ORGANIC CARBON IN INDIAN DARK EARTH IN APUÍ REGION, AM
}

\author{
VARIABILIDADE E CORRELAÇÃO ESPACIAL DE AGREGADOS E CARBONO \\ ORGÂNICO EM TERRA PRETA DE ÍNDIO NA REGIÃO DO APUÍ, AM
}

\author{
Romário Pimenta GOMES ${ }^{1}$; Milton César Costa CAMPOS $^{2}$; Wildson Benedito Mendes \\ BRITO $^{2}$; José Maurício da CUNHA ${ }^{2}$; Aleksander Westphal MUNIZ ${ }^{3}$; Laércio Santos SILVA ${ }^{1}$; \\ Edicarlos Damacena de SOUZA ${ }^{4}$ Ivanildo Amorim OLIVEIRA ${ }^{5}$; Ludmila de FREITAS ${ }^{5}$ \\ 1. Faculdade de Ciências Agrárias e Veterinárias, Universidade Estadual Paulista - FCAV/UNESP, Jaboticabal, SP, Brasil. \\ rpgagronomia@gmail.com; 2. Universidade Federal do Amazonas - UFAM, Humaitá, AM, Brasil; 3. Embrapa Amazônia Ocidental, \\ Manaus, AM, Brasil; 4. Universidade Federal de Rondonópolis - UFR, Rondonópolis, MT, Brasil; 5. Instituto Federal de Educação, \\ Ciência e Tecnologia do Pará - IFPA, Breves, PA, Brasil.
}

\begin{abstract}
Having in mind the importance of knowing the variability and spatial correlation of soil properties in Indian Dark Earth (IDE), we evaluated in this study the variability and the spatial correlation of aggregates and carbon in an Ultisol under coffee cultivation in southern Amazonas. It was established a 48 x $88 \mathrm{~m}$ sampling grid spaced 06 x $08 \mathrm{~m}$, totalling 88 sampling points. Then soil samples were collected at: $0.0-0.05,0.05-0.10$, and $0.10-0.20 \mathrm{~m}$ layers. The spatial variability of the Mean Weighted Diameter (MWD) attributes, aggregates $>2 \mathrm{~mm},<2 \mathrm{~mm}$, bulk density (BD) and organic carbon (OC) was analyzed by adjusting the simple semivariograms, while spatial correlations of the $\mathrm{OC}$ with aggregates and BD were analyzed by cross-semivariogram. We could conclude that there was spatial dependence in the variables, wherein the largest ones were observed at 0.0-0.05 m, except for Mean Weighted Diameter (MWD) and aggregates greater than $2.00 \mathrm{~mm}$ with larger range of values in depth from 0.05-0.10 and 0.10-0.20 m. The mean weight diameter and aggregate class attributes greater than $2.00 \mathrm{~mm}$ had negative spatial correlation with organic carbon at 0.0-0.05 m, while the smaller aggregates than $2.00 \mathrm{~mm}$ classes and bulk density correlated positively with organic carbon at $0.0-0.05 \mathrm{~m}$ and $0.10-0.20 \mathrm{~m}$.
\end{abstract}

KEYWORDS: Soil aggregation. Geostatistics. Cross variogram.

\section{INTRODUCTION}

The spatial variability attributes of the soil system occurs naturally and in different levels. It can be due to the intrinsic pedogenic factors and processes of soil formation and its interactions with the landscape, as well associated to the management (MARQUES JÚNIOR et al., 2008). Soil revolving by practices such as plowing, and gradation change the variability of the organic matter of the soil and properties influenced by it, as soil density and resistance to penetration, porous space and soil water movement can change the variability of organic matter and soils (SOARES et al 2016; Gomes et al., 2006) et al., 2017). In his investigation Corá et al. (2004) conclude that soil management altered the spatial dependence of chemical attributes and soil clay content on the surface layer to decrease the spatial variability of the attributes in relation to the deeper layer. In the Amazon region, the conversion of the Black Earth of Indians for agricultural purposes has caused alterations in the soil properties, that is, conditioning a new spatial pattern of soil attributes (Aquino et al., 2014).

Being aware of it, the use of geostatistic techniques have being employed in the last years, aiming quantify the existence of spatial variations in the several physical attributes, allowing a detailed description of these properties through space (CAMPINAS et al., 2013). When we know the spatial dependence of the soil attributes we can evaluate the spatial correlation between the attributes by a cross semivariogram (CAMARGO et al., 2008), as shown in the Schaffrath et al. (2008) studies related to the soil physical attributes and Camargo et al. (2008) with the mineralogy and soil aggregates.

The Amazonas is the biggest state of Brazil. It is rich geologically and geomorphologically, consequently in its landscapes, reflecting in diversity in the regional flora. However, the surveys done in the Amazonian region are mostly generic, where detailed information is always missing (OLIVEIRA et al., 2015), being necessary the dissemination by geostatistic, an easier tool which needs less labor time and allows a better mathematic accuracy estimative values among the georeferenced points.

In this sense, papers (OLIVEIRA et al., 2013; ALHO et al., 2014; AQUINO et al., 2014; SOARES et al., 2015) have shown data evaluating the spatial dependence structure in grassland and 
forest environments. Aquino et al. (2015) in five different areas in south of Amazonas and Silva et al. (2016) evaluating the geometric mean diameter (GMD) and organic carbon (OC) in a cultivated land under IDE in the Apuí region, AM, both had a spatial continuity to most of analyzed attributes, remembering that this tool improving can help in a better understanding and interpretation of this region soil attributes spatial variability.

The study of variability associated to the soil attributes spatial correlation, as OC and its relations with other physical attributes in anthropogenic environments with a so-intimate character like the IDEs, is unprecedented in the Amazonian region. Based on we presented before, in this work we evaluated the variability and spatial correlation of organic carbon, bulk density, as well aggregates classes in area of Indian Dark Earth in Apuí, southern of Amazonas.

\section{MATERIAL AND METHODS}

The evaluated area is situated in the southern of Amazonas state, bordering the Transamazonic Road BR 230, in Apuí. This area is in an Indian Dark Earth, with coffee plants, at $7^{\circ} 12^{\prime}$ $05^{\prime \prime}$ south latitude and $59^{\circ} 39^{\prime} 35^{\prime \prime}$ west longitude. The soil has being used as agricultural land for six years (two years of grass and four years of coffee) (Figure 1). Its classification is Eutrophic Yellow Argisol according to Embrapa (2013). This soil is equivalent to the Ultisol (SOIL SURVEY STAFF, 2014).

The geology is composed by sandstone of Beneficent formation, recovered by a clay pack of tertiary. In it is prevailed the primary vegetation formed by Dense Tropical Forest, with densified trees. The weather in the region is classified (Köppen classification) as rainy tropical, with a short dry period (Am). The temperatures vary from $25{ }^{\circ} \mathrm{C}$ to $27{ }^{\circ} \mathrm{C}$ and the pluvial precipitations vary from 2.250 to $2.750 \mathrm{~mm}$ annually, where the rains are concentrated from October to June (BRAZIL, 1978).

The coffee sampling area is $4,228 \mathrm{~m}^{2}$ in a grid of 88 points spaced $8 \times 8 \mathrm{~m}$, totalizing 88 sampling points (Figure 1). After this, we opened small trenches, where we collected the soil samples at the lays of $0.0-0.05,0.05-0.10$, and $0.10-0.20 \mathrm{~m}$ at the crossing points, totalizing 264 soil samples. These points were georeferenced using the GPSMAP 76CS (Garmin International, USA).

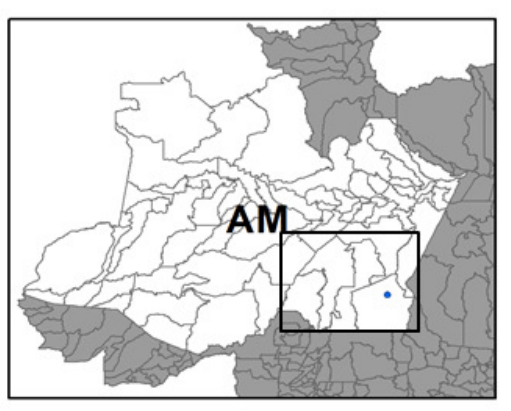

Legend

- Coffee area

City

Amazonas

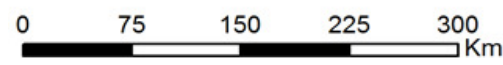

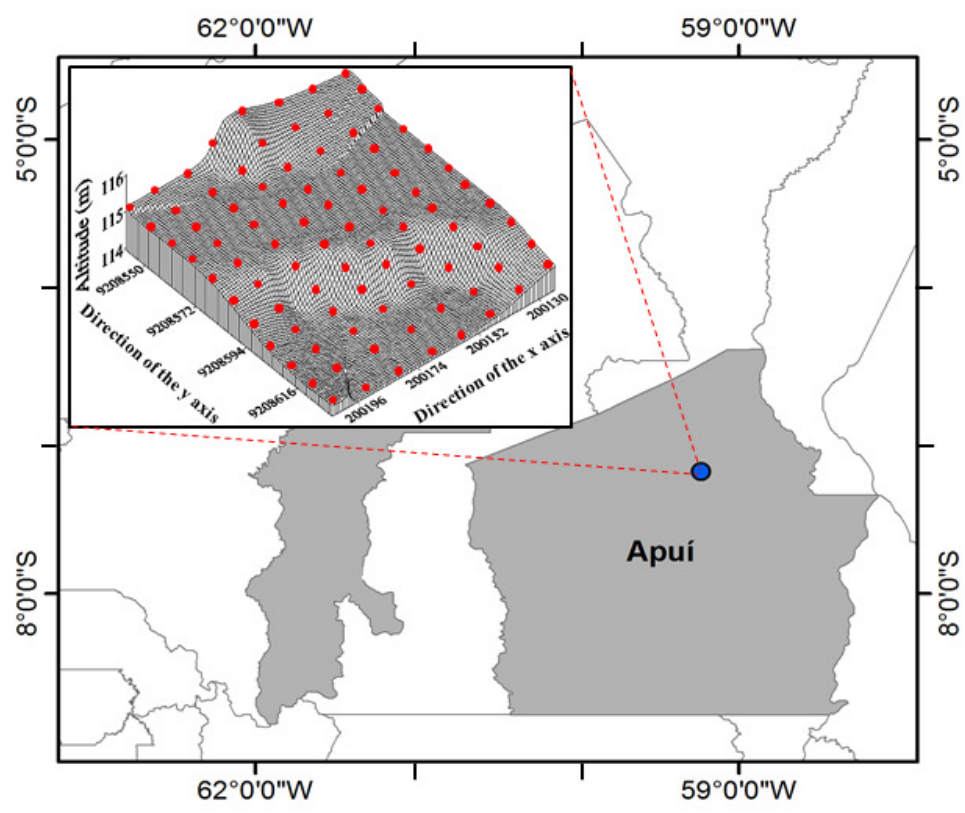

Figure 1. Localization map and sampling grid digital elevation model in Indian Dark Earth under coffee growth in Apuí, AM.

For physical characterization, the particle size analysis was obtained by the pipette method, using $0.1 \mathrm{~mol} \mathrm{~L}^{-1}$ of $\mathrm{NaOH}$. The clay fraction was separated by sedimentation, total sand by sieving, and silt was calculated based on the difference between them. The clay fraction was determined by the pipette method, the sand by sieving and silt was calculated by the difference (EMBRAPA, 2011). The results are presented at Table 1 . 
Table 1. Soil texture in the area of Archaeological Dark Earth under coffee cultivation.

\begin{tabular}{cccc}
\hline \multirow{2}{*}{ Layers } & Sand & Silt & Clay \\
\cline { 2 - 4 } & & $\mathrm{g} \mathrm{kg}^{-1}$ & \\
\hline $0.0-0.05 \mathrm{~m}$ & 364.65 & 617.37 & 17.98 \\
$0.05-0.10 \mathrm{~m}$ & 417.69 & 567.98 & 14.33 \\
$0.10-0.20 \mathrm{~m}$ & 344.32 & 638.52 & 17.16 \\
\hline
\end{tabular}

The bulk density (BD) was determined in samples with preserved structure, in a volumetric cylinder $(5.57 \mathrm{~cm}$ diameter and $4.1 \mathrm{~cm}$ high) and then dried at $105-110{ }^{\circ} \mathrm{C}$ in an oven during 48 hours (EMBRAPA, 2011). Organic carbon (OC) was determined following the Yeomans and Bremner (1988) recommendations.

Soil samples were removed in blocks, which were air dried and passed through $9.52 \mathrm{~mm}$ and 4.76 $\mathrm{mm}$ sieves. Then, $20 \mathrm{~g}$ samples of the retained aggregates in the $4.76 \mathrm{~mm}$ sieve were used in the wet aggregate stability analysis and subjected to vertical oscillations for 15 minutes (KEMPER; CHEPIL, 1965). Results were expressed as Mean Weighted Diameter (MWD), percentage of aggregates greater than $2 \mathrm{~mm}(\%>2 \mathrm{~mm})$ and percentage of aggregates smaller than $2 \mathrm{~mm}(\%<2$ $\mathrm{mm})$.

Data exploratory analysis was performed by calculating mean, median, coefficient of variation $(\mathrm{CV})$, skewness, kurtosis and the KolmogorovSmirnov test. The CV was calculated based on the Warrick and Nielsen (1980) criterion that classifies the $\mathrm{CV}$ as low $(\mathrm{CV}<12 \%)$, medium (from 12-24 $\%)$ and high $(\mathrm{CV}>24 \%)$.

The spatial variability of all variables of this study was evaluated through geostatistics (MATHERON, 1963; McBRATNEY; WEBSTER, 1981; VIEIRA et al., 1983; ISAAKS; SRIVASTAVA, 1989; CAMARGO et al., 2008; AQUINO et al., 2014; SILVA et al., 2016; CUNHA et al., 2018), using the GS +8.0 software (ROBERTSON, 1998). The experimental semivariogram was estimated under the hypothesis of stationarity, by the equation (1):

$$
\hat{\gamma}(h)=\frac{1}{2 N(h)} \sum_{i=1}^{N(h)}\left[Z\left(x_{i}\right)-Z\left(x_{i}+h\right)\right]^{2}
$$

where: $\gamma(\mathrm{h})$ - the semivariance value in a distance $\mathrm{h}$; $\mathrm{N}(\mathrm{h})$ - number of pairs involved in the semivariance calculation; $\mathrm{Z}\left(\mathrm{x}_{\mathrm{i}}\right)$ - value of attribute $\mathrm{Z}$ in position $x_{i} ; Z\left(x_{i}+h\right)$ - value of attribute $Z$ separated by a distance $\mathrm{h}$ from position $\mathrm{x}_{\mathrm{i}}$.

The estimation of the spatial correlation between two variables with all possible combinations, according to Holmes et al. (2005), was performed by the construction of the crosssemivariogram, using the methodology developed by (DEUTSCH, JOURNEL, (1998), which is expressed by equation 2 :

$$
\hat{y}(h)=\frac{1}{2 N(h)} \sum_{i=1}^{N(h)}\left[Z\left(x_{i}\right)-Z\left(x_{i}+h\right)\right]\left[y\left(\mathbf{X}_{\mathrm{i}}\right)-\mathrm{y}\left(\mathrm{x}_{\mathrm{i}}+\mathrm{h}\right)\right]
$$

(2)

Where:

$\hat{y}(h)$ - semivariance value for the $\mathrm{h}$ vector; $N(h)$ - number of pairs involved in the semivariance calculation; $Z\left(x_{i}\right)$ - value of $\mathrm{Z}$ attribute in the $\mathrm{xi}$ position; $\mathrm{y}\left(\mathrm{x}_{\mathrm{i}}\right)$ the value of the secondary variable at point $i ; Z\left(x_{i}+h\right)$ - value of $\mathrm{Z}$ attribute separated by a distance $\mathrm{h}$ from the $x i$ position (VIEIRA, 2000).

In order to analyze the spatial correlation between OC (main variable) and Mean Weighted Diameter (MWD), aggregates $>2.00 \mathrm{~mm},<2.00$ $\mathrm{mm}$ and soil density (BD) (secondary variable), cross semivariograms were developed. This analysis allows to verify the correlation between the attributes, which can assume both positive values, indicating that the increase in one attribute is accompanied by the increase of the other, as negative, that is, that the increase of one of the attributes gives the decrease of the other (BHATTI et al., 1991, CAMARGO et al., 2008).

Permissible mathematical models were adjusted to the semivariograms and estimated experimental semivariograms estimating the following effects: nugget $\left(\mathrm{C}_{0}\right)$, threshold $\left(\mathrm{C}_{0}+\mathrm{C}_{1}\right)$, and range $(\mathrm{r})$. They were based on the pairs involved in the calculation of each point of the experimental semivariogram, based on the sum of the squared residuals (SQR), the estimation of the landing and the coefficient of determination $\left(\mathrm{R}^{2}\right)$. Then, the cross-validation $(\mathrm{CV})$ technique was applied to test all the models adjustment procedures (Vieira, 2000). Subsequently, the degree of spatial dependence (DSD) was succeeded by the relation between the nugget effect $(\mathrm{CO})$ and semivariogram plateau $(\mathrm{C} 0+\mathrm{C} 1)$. Attributes were considered with strong DSD when the relation was $[\mathrm{C} 0 /(\mathrm{C} 0+\mathrm{C} 1) \leq 25 \%]$, moderate DSD $[(\mathrm{C} 0 /(\mathrm{C} 0+\mathrm{C} 1)$ between 25 and $75 \%]$ and weak DSD when $[(\mathrm{C} 0 /(\mathrm{C} 0+\mathrm{C} 1)>75 \%$ (CAMBARDELLA et al., 1994). Finally, we performed variable value distribution estimates to points not sampled in the grid by ordinary kriging.

The estimation of the distribution of variable values for the unsampled points in the grid 
was performed by kriging using the Surfer program (SURFER FOR WINDOWS, 1999).

\section{RESULTS AND DISCUSSION}

The results referring to the descriptive statistical analysis showed that a large part of the studied variables adjusted to the normality, depending on the depth (Table 2). The proximity of the mean and median values indicates a symmetrical distribution of the data (CAJAZEIRA; ASSIS JÚNIOR, 2011), which can be confirmed by the asymmetry and kurtosis coefficients, with values close to zero. According to the KolmogorovSmirnov test, only the MWD showed normal distribution at all depths. Except for BD at 0.10-0.20 $\mathrm{m}$, the other attributes adjusted to the normal distribution.

Table 2. Mean Weighted Diameter (MWD) descriptive statistics, aggregate class greater than $2 \mathrm{~mm}(>2 \mathrm{~mm})$, aggregate class smaller than $2 \mathrm{~mm}(<2 \mathrm{~mm})$, bulk density (BD) and organic carbon (OC) in IDE area with coffee growth in Apuí, AM.

\begin{tabular}{|c|c|c|c|c|c|c|c|}
\hline \multirow[b]{2}{*}{ Descriptive Statistics } & \multirow[b]{2}{*}{ Depth. (m) } & \multirow[b]{2}{*}{ Mean } & \multirow[b]{2}{*}{ Median } & \multicolumn{3}{|c|}{ Coefficients } & \multirow[b]{2}{*}{$d^{(1)}$} \\
\hline & & & & Variation $(\%)$ & Asymmetry & Kurtosis & \\
\hline \multirow{3}{*}{ MWD (mm) } & $0.0-0.05$ & 3.04 & 3.14 & 3.18 & -0.29 & -0.24 & $0.20 *$ \\
\hline & $0.05-0.10$ & 3.02 & 3.10 & 3.18 & -0.32 & -0.59 & $0.20 *$ \\
\hline & $0.10-0.20$ & 2.90 & 2.91 & 4.82 & -0.32 & -0.44 & $0.20 *$ \\
\hline \multirow{3}{*}{$>2 \mathrm{~mm}(\%)$} & $0.0-0.05$ & 90.60 & 91.26 & 4.95 & -0.28 & -0.45 & $0.08 *$ \\
\hline & $0.05-0.10$ & 88.59 & 86.95 & 8.37 & -0.47 & -0.50 & 0.02 \\
\hline & $0.10-0.20$ & 81.58 & 81.99 & 8.05 & -0.37 & -0.40 & $0.20 *$ \\
\hline \multirow{3}{*}{$<2 \mathrm{~mm}(\%)$} & $0.0-0.05$ & 7.65 & 6.65 & 53.04 & 0.55 & -0.30 & 0.01 \\
\hline & $0.05-0.10$ & 14.40 & 13.04 & 49.79 & 0.76 & -0.08 & 0.02 \\
\hline & $0.10-0.20$ & 13.83 & 12.95 & 50.25 & 0.62 & -0.12 & $0.20 *$ \\
\hline \multirow{3}{*}{$\mathrm{BD}\left(\mathrm{kg} \mathrm{dm}^{-3}\right)$} & $0.0-0.05$ & 1.80 & 1.09 & 9.25 & 0.23 & 0.22 & $0.20 *$ \\
\hline & $0.05-0.10$ & 1.16 & 1.18 & 9.25 & -0.20 & -0.26 & $0.20 *$ \\
\hline & $0.10-0.20$ & 2.22 & 2.20 & 12.62 & 0.51 & 1.01 & 0.001 \\
\hline \multirow{3}{*}{$\mathrm{OC}\left(\mathrm{g} \mathrm{kg}^{-1}\right)$} & $0.0-0.05$ & 38.96 & 37.25 & 29.85 & 0.38 & -0.85 & 0.03 \\
\hline & $0.05-0.10$ & 34.96 & 37.79 & 29.85 & -0.33 & -0.67 & 0.001 \\
\hline & $0.10-0.20$ & 31.66 & 32.35 & 17.37 & -0.72 & 0.24 & $0.20 *$ \\
\hline
\end{tabular}

(1) d: Kolmogorov-Smirnov normality test, * significant at $5 \%$ of probability.

Assuming the classification criteria for the coefficient of variation (CV) proposed by Warrick and Nielsen (1980), the only attribute with high variability in all depths was the class of aggregates $<2.00 \mathrm{~mm}$, while the OC showed high variability in the depths $0.0-0.05$ and $0.05-0.10 \mathrm{~m}$ and average depth $0.10-0.20 \mathrm{~m}$ (Table 2), corroborating with Corado Neto et al. (2015) results. For MWD, aggregates $>2.00 \mathrm{~mm}$ and $\mathrm{BD}$ showed low values of $\mathrm{CV}$, except for BD in depth $0.10-0.20 \mathrm{~m}$, with mean CV value. Similar behavior was verified by Aquino et al. (2014) and Alho et al. (2014) in the southern region of Amazonas. Despite the high CV value observed in this study, we can observe that in $53 \%$ of the studied attributes a low variability is predominant, indicating an environment with low heterogeneity. 
Although the CV allows comparing the variability between variables among different units, this information has gained repercussion in the scientific scope (Table 2). Some authors suggest that the use of CV should not be generalized, since this coefficient does not allow evaluate neither the spatial variability of soil attributes, nor its spatial pattern (SIQUEIRA et al., 2010). In this aspect, the geostatistics is the most suitable tool to characterize the distribution of one or more (regionalized) variables with a spatial-dependent structure (CARVALHO et al., 2011, AQUINO et al., 2014).

The semivariogram estimates are showed in the Figure 2. The predominant model which better adjusts the MWD attributes of experimental
GOMES, R. P. et al.

semivariograms and aggregates $(>2.00 \mathrm{~mm}$ and $<$ $2.00 \mathrm{~mm}$ ) in all depths was the exponential one. The spherical model better adjusted to BD at 0.0 $0.5 \mathrm{~m}$ and $0.5-0.10 \mathrm{~m}$ depths. Yet, at $0.10-0.20 \mathrm{~m}$ depth, it was adjusted to the exponential model. For OC, the adjusted model was the exponential one at $0.0-0.05 \mathrm{~m}$ depth and the spherical one at $0.05-0.10$ and $0.10-0.20 \mathrm{~m}$. These results agree with the ones belonged to Souza et al. (2009) and Corado Neto et al. (2015). This behavior evidences variation in the geospatialization of variables, abruptly for both MWD and classes of aggregates. In contrast, BD and OC presented soft (spherical) to abrupt (exponential) changes depending on the depth.

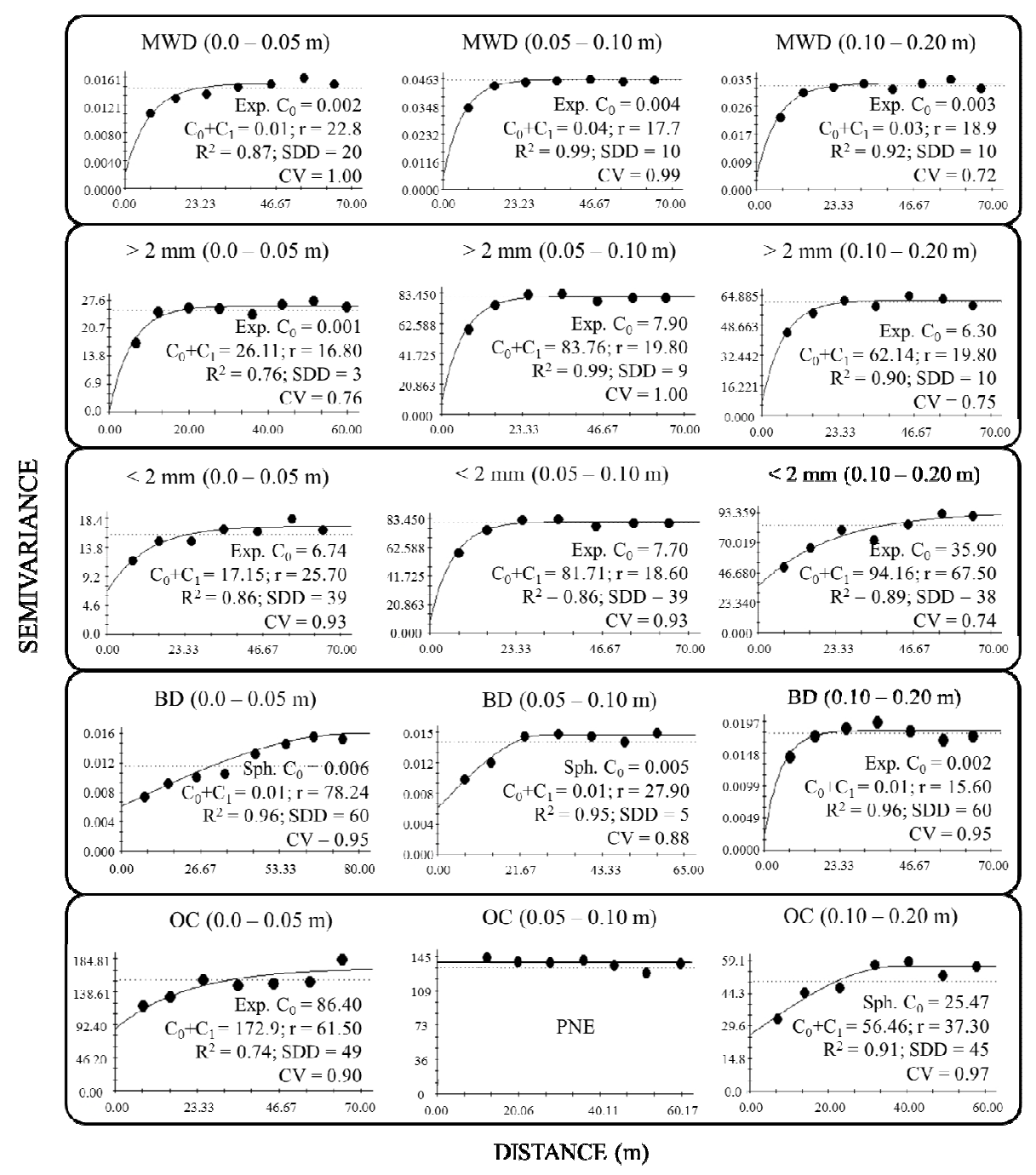

Figure 2. Semivariograms of the mean weighted diameter (MWD, mm), aggregate class greater than $2 \mathrm{~mm}(>2$ $\mathrm{mm}$ ), aggregate class smaller than $2 \mathrm{~mm}(<2 \mathrm{~mm})$, bulk density $\left(\mathrm{BD}, \mathrm{kg} \mathrm{dm}^{-3}\right)$ and organic carbon $\left(\mathrm{OC}, \mathrm{g} \mathrm{kg}^{-1}\right)$ in three layers in IDE area in Apuí, AM. The acronyms correspond respectively to the model $(\operatorname{Exp}=$ Exponential, $\mathrm{Sph}=$ Spherical $)$, pure nugget effect $=\mathrm{PNE}$, nugget effect $=\mathrm{C}_{0}$, Landing $=\mathrm{C}_{0}+\mathrm{C}_{1}$ and the range $(\mathrm{m})=\mathrm{r}, \mathrm{R}^{2}=$ coefficient of determination; SDD $\%$ = spatial dependence degree and $\mathrm{CV}=$ cross-validation. 
When we analyze the relation between the nugget effect $\left(\mathrm{C}_{0}\right)$ and the threshold $\left(\mathrm{C}_{0}+\mathrm{C}_{1}\right)$ (Figure 2), which reports the spatial dependence degree (SDD), according to the classification proposed by Cambardella et al. (1994), we evidence that the attributes MWD and aggregates $>2.00 \mathrm{~mm}$ presented strong spatial dependence at all depths $\left[\mathrm{C}_{0} /\left(\mathrm{C}_{0}+\mathrm{C}_{1}\right) \leq 25 \%\right]$. The BD at 0.0-0.05 $\mathrm{m}$ depth was characterized as moderate spatial dependence $\left[\mathrm{C}_{0} /\left(\mathrm{C}_{0}+\mathrm{C}_{1}\right)\right.$ between 25 e $\left.75 \%\right]$ and strong at 0.05 0.10 and $0.10-0.20 \mathrm{~m}$ depths. The OC followed this same behavior. Carvalho et al. (2003) reinforce that the moderate spatial dependence is attributed to factors extrinsic to the soil, such as the adopted management, while Cambardella et al. (1994) attribute the strong spatial dependence to the intrinsic soil characteristics controlled by natural conditions, such as pedogenetic processes, mineralogical characteristics and landscape.

The extent of spatial dependence (Figure 2) represents an important parameter of the geostatistics in the interpretation of semivariograms, because its determines the limit distance in which a regionalized variable presents continuity in space, that is, so far the sampled points correlate with each other (MATIAS et al., 2013). Thereafter, the lower the range, the greater the spatial variability of the attributes (MARQUES JÚNIOR et al., 2008). In this sense, the attributes studied presented different range values, varying from 12.60 to $78.34 \mathrm{~m}$, and all values above the established one in the sample mesh, indicate greater spatial continuity of soil properties.

We observed influence in the range values as a function of depth. Among the variables studied, the $\mathrm{BD}$ assumed the extreme range positions, with a greater range $(78.24 \mathrm{~m})$ at $0.0-0.05 \mathrm{~m}$ and the smaller range $(15.60 \mathrm{~m})$ at $0.10-0.20 \mathrm{~m}$, suggesting that the Ds is more homogeneous at the surface with respect to the subsurface. This disparity is attributed to the management, which tends to standardize the superficial layer of the soil, mainly reflecting the $\mathrm{BD}$, considered the physical attribute sensitive to the variations of the management to which the soil is submitted (MOTA et al., 2013).

We can observe that MWD and aggregates $>2.00 \mathrm{~mm}$ have more homogeneous range values for all depths when compared to the other variables. In addition, the continuity in the spatial distribution for MWD was greater at $0.0-0.05 \mathrm{~m}$, while aggregates $>2.00 \mathrm{~mm}$ tended to stabilize from 0.05 $0.10 \mathrm{~m}$ depth. The homogeneous pattern for aggregates $>2.00 \mathrm{~mm}$ revealed that the soil management little influenced variability of this attribute, allowing to conclude that its spatial dependence in the studied area, in the layers 0.05$0.10 \mathrm{~m}$ and $0.10-0.20 \mathrm{~m}$, is governed by the natural characteristics of the soil.

The OC at $0.05-0.10 \mathrm{~m}$ showed pure nugget effect (PNE), which is the absence of spatial dependence, once the structural part of spatial dependence is defined with only one point. The possible causes for such behavior can be attributed to the analytical error or undetected variations, based on the sampling distance used in the grid. Therefore, it is necessary to reduce the sampling distance to capture the semivariance of this variable (CARVALHO et al., 2011).

In general, the range values tended to decrease in depth for the attributes MWD, BD, and OC, showing greater spatial variability as it advances in the soil profile, accordingly with the results of Alho et al. (2014). Tavares et al. (2012) evaluating the spatial relationship of physical attributes of a Cohesive Argisol cultivated with sugarcane, found range values for $\mathrm{BD}$ and $\mathrm{OC}$ decreasing with depth. According to the authors, this was because the management tended to standardize the spatial pattern of $\mathrm{BD}$ and $\mathrm{OC}$ in the topsoil. While in depth the greater spatial variability is subordinated to the natural characteristic of the soil, little affected by the management. Similarly, Corá et al. (2004) report that in the superficial layer the soil management tends to decrease the spatial variability of the attributes in relation to the deeper layer, depending on the management. This finding justifies the moderate classification and strong spatial dependence obtained for BD and OC in the present study.

In order to better understand the spatial similarity of the evaluated attributes, cross-linked semivariograms were constructed, setting the OC and correlating spatially with other attributes, at the respective depths in question (Figure 3). The results showed that the spatial continuity of the crosssemivariograms was different among the attributes as a function of depth. We found spatially negative correlations between MWD x OC, and class of aggregates greater than $2.00 \mathrm{~mm}$ at $0.0-0.05 \mathrm{~m} \mathrm{x}$ OC, at the same depth aggregates smaller than 2.00 $\mathrm{mm} \times \mathrm{OC}$. Appropriate explanation for this atypical behavior is due to the greater proportion of the silt and sand (40 and 29 fold respectively), to the amount of clay. The physical-chemical characteristics of the sand fraction, such as, absence of surface load and low specific surface, impart its non-cohesive character (BRADY; WEIL, 2008), imparing the union between inorganic and organic particles of the soil. 


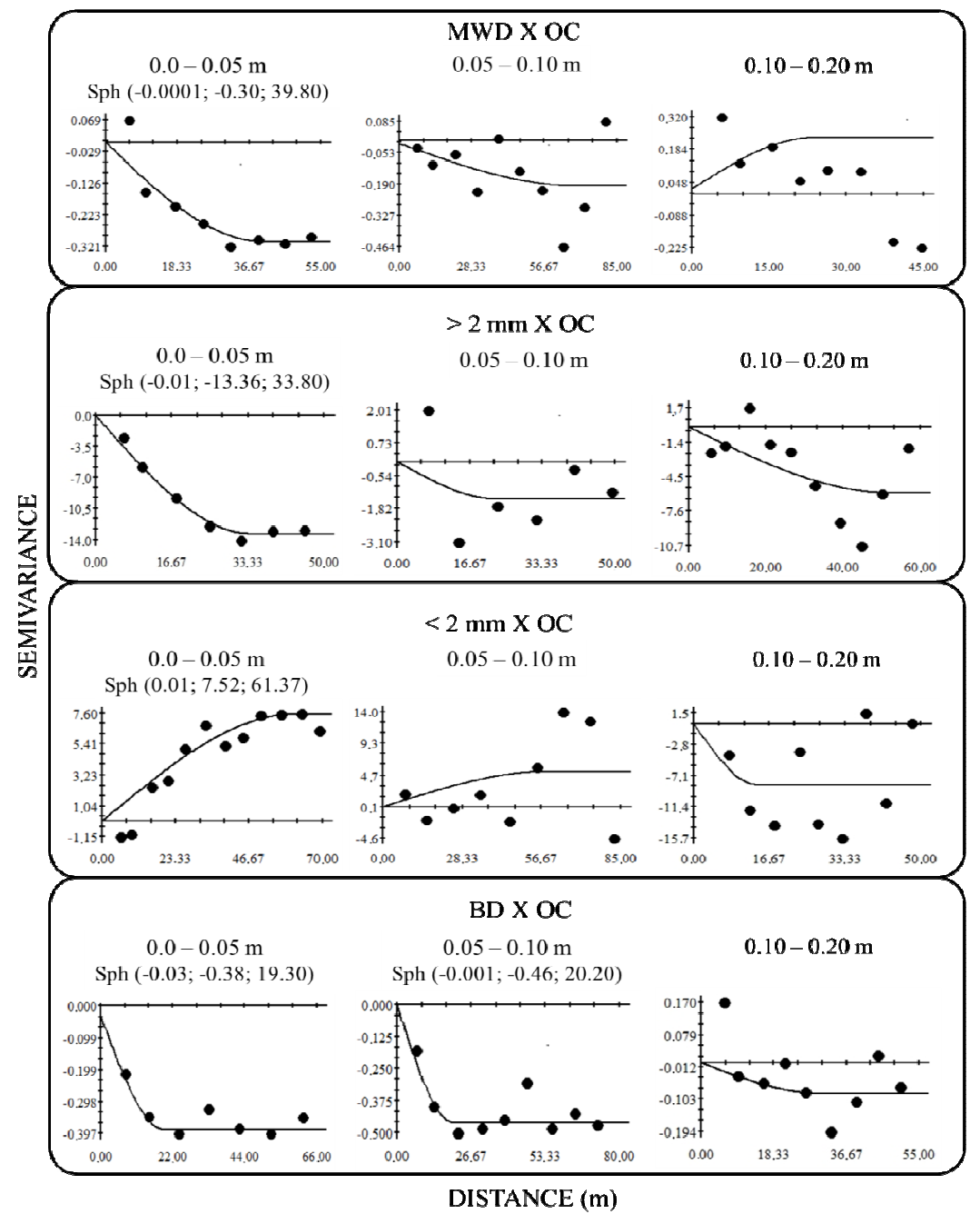

Figure 3. Crossing semivariograms and the mathematical model adjusted in the attributes: the mean weighted diameter (MWD, $\mathrm{mm}$ ), aggregate class greater than $2 \mathrm{~mm}(>2 \mathrm{~mm}$ ), aggregate class smaller than 2 $\mathrm{mm}(<2 \mathrm{~mm})$, bulk density $\left(\mathrm{BD}, \mathrm{kg} \mathrm{dm}^{-3}\right)$ and organic carbon $\left(\mathrm{OC}, \mathrm{g} \mathrm{kg}^{-1}\right)$ in IDE area with coffee plants in Apuí, AM. Spherical model $(\mathrm{Sph})$ and values into the parameters are respectively the nugget effect $=\mathrm{C}_{0}$, landing $=\mathrm{C}_{0}+\mathrm{C}_{1}$ and the range $(\mathrm{m})=\mathrm{r}$.

The positive behavior of OC $\mathrm{x}$ smaller than $2.00 \mathrm{~mm}$ is due to the effectivity of organic matter and clay that, when they associate, they link the smaller particles of soil. On this assertion, Lima and Anderson (1997) attribute this behavior to the mineralogy of the clay fraction, constituted almost solely by oxides and hydroxides of $\mathrm{Fe}$ and $\mathrm{Al}$, becomes more affective in the genesis of smaller aggregates, once the oxides are flocculating agents.

Regarding the size of aggregates, Passos et al. (2007) state that the smallest aggregates present higher clay content associated with organic matter and this chelation is responsible for the higher stock of organic matter in the soil, that is, a higher stock of OC. In this sense, the cross-semivariogram in fully illustrated this behavior, showing similarity in the spatial dependence structure up to $61.37 \mathrm{~m}$ distance at 0.0-0.05 m.
The negative spatial correlation for $\mathrm{BD} \mathrm{x}$ OC and with the close range values at depths 0.0$0.05 \mathrm{~m}(\mathrm{r}=19.30 \mathrm{~m})$ and $0.05-0.10 \mathrm{~m}(\mathrm{r}=22.20 \mathrm{~m})$ showed that these variables have a similar limit of spatial dependence, that is, they would co-occur simultaneously in space at these distances. This is due to the greater part of the coffee plant root system at $0.30 \mathrm{~m}$ depth (GUIMARÃES; LOPES, 1986), as well as the natural and anthropogenic increase of organic carbon in the IDEs. This inverse correlation is already well understood in the literature (VASCONCELOS et al., 2014; ALHO et al., 2014).

The evaluated attributes isoline and surface maps presented a large amplitude of the studied attributes (Figure 4). When analyzed, these maps present clearly that the evaluated soil attributes variability is dependent mainly of depth and 
landscape variations (Figure 4). We can observe that at $0.0-0.5 \mathrm{~m}$ depth, the MWD, aggregates $>2.00$ $\mathrm{mm},<2.00 \mathrm{~mm}$, and OC presented higher spatial variability, thanks to the management in the surface and the surface landscape itself allows a higher soil attributes spatial variability (MARQUES JÚNIOR et al., 2008).

On the other hand, in $0.0-0.05 \mathrm{~m}$ the attributes MWD, BD and OC, and aggregates $>2.00$ $\mathrm{mm}$ in the layers $0.0-0.05$ and $0.10-0.20 \mathrm{~m}$, as well as aggregates $<2.00$ to $0.10-0.20 \mathrm{~m}$, presented a better defined spatial distribution (Figure 4). This
GOMES, R. P. et al.

more continuous spatialization can be verified by the maximum values of semivariograms reached and the greater distance of the isolines, parameters that prove the smaller spatial variability. The peculiarity found for the attributes in the space in the evaluated layers reinforces that the soil management changes the physical attributes differently, consistent with the results of other soil studies under coffee cultivation (CARVALHO et al., 2013; MOTA JR et al., 2017) and other crops (AQUINO et al., 2014, ALHO et al., 2014).
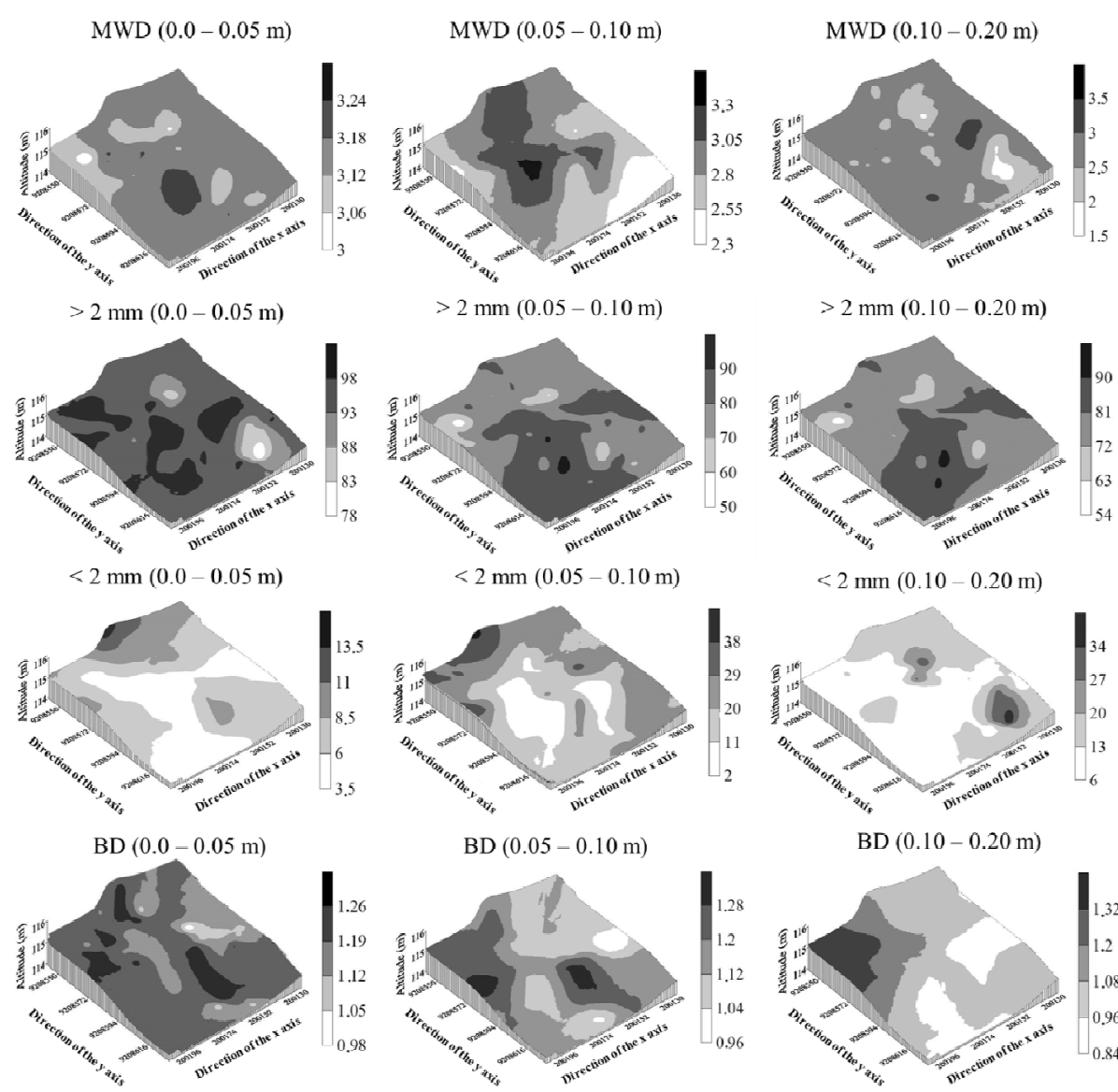

$\mathrm{BD}(0.10-0.20 \mathrm{~m})$

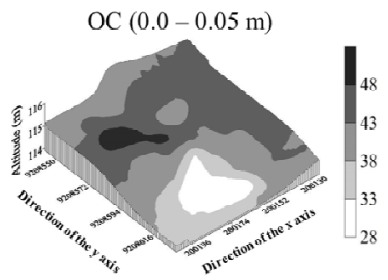

OC $(0.05-0.10 \mathrm{~m})$

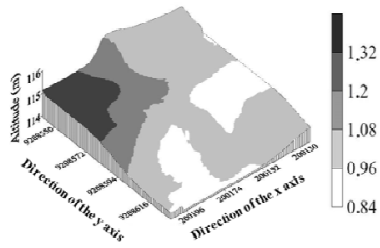

OC $(0.10-0.20 \mathrm{~m})$

PNE

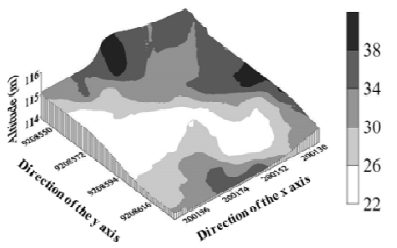

Figure 4. Distribution isolines maps of the mean weighted diameter (MWD, mm), aggregate class greater than $2 \mathrm{~mm}(>2 \mathrm{~mm})$, aggregate class smaller than $2 \mathrm{~mm}(<2 \mathrm{~mm})$, bulk density (BD, $\left.\mathrm{kg} \mathrm{dm}^{-3}\right)$, organic carbon (OC, $\mathrm{g} \mathrm{kg}^{-1}$ ) and pure nugget effect $=$ PNE in three layers in IDE area in Apuí, AM.

In this aspect, in the compartments with lower OC contents, the lower values of MWD are similar to the larger ones of $\mathrm{BD}$ and aggregates < $2.00 \mathrm{~mm}$ at $0.5-0.10$ and $0.10-0.20 \mathrm{~m}$ (Figure 4).
Thus, the lower values of MWD are reflections of the higher $\mathrm{BD}$, so the low values of $\mathrm{BD}$ are result of the high OC content evidenced in IDE soils, according to Oliveira et al. (2015). 
Recent studies (MOTA JR et al., 2017) also found, near to the study area, in depth of BD in IDE area under coffee. For these authors, this is due to reduction of $\mathrm{OM}$ content and covariate variables as OC in the more subsurface horizons of the soil, since the accumulation of $\mathrm{CO}$ in coffee cultivation is concentrated on the soil surface and its roots do little to contribute to OC in depth. In general, in addition to the geomorphological aspects, the coffee crop management changed spatial variability, corroborating studies by Mota Jr et al. (2017) and Carvalho et al. (2013) under coffee cultivation. Thus, the knowledge of the spatial distribution of soil physical attributes becomes important for the refinement of the appropriate management practices and evaluation of the effect of agriculture on the soil physical quality of the IDEs.

\section{CONCLUSIONS}

The evaluated variables presented structures of spatial dependence, and the largest reaches are found at 0.0-0.05 m, except for MWD and aggregates larger than $2.00 \mathrm{~mm}$, with greater range values at $0.05-0.10$ and $0.10-0.20 \mathrm{~m}$.

The weighted mean diameter and classes of aggregates greater than $2.00 \mathrm{~mm}$ attributes present negative spatial correlation with organic carbon at 0.0-0.05 m, while to classes of aggregates smaller than $2.00 \mathrm{~mm}$ and bulk density showed a positive spatial correlation with organic carbon at 0.0-0.05 and $0.10-0.20 \mathrm{~m}$.

RESUMO: Considerando a importância do conhecimento da variabilidade e correlação espacial dos atributos do solo em Terra Preta de Índio (TPIs), avaliou-se neste trabalho a variabilidade e a correlação espacial de agregados e carbono em um Argissolo Amarelo eutrófico sob cultivo de café na região sul do Amazonas. Foi estabelecido um grid amostral com dimensões de 48 × 88 m e espaçamentos de 06 × 08 m, totalizando 88 pontos amostrais. Em seguida, foram coletadas amostras de solos nas profundidades: 0,0-0,05, 0,05-0,10, e 0,10-0,20 m. A variabilidade espacial dos atributos diâmetro médio ponderado (DMP), agregados $>2 \mathrm{~mm},<2 \mathrm{~mm}$, densidade do solo (Ds) e carbono orgânico (CO) foi analisada ajustando os semivariogramas simples, enquanto as correlações espaciais do CO com agregados e Ds foram analisadas por semivariogramas cruzados. Concluiu-se que as variáveis apresentaram dependência espacial, e os maiores alcances são constatados na profundidade 0,0-0,05 m, exceto para DMP e agregados maiores que 2,00 mm com maiores valores de alcance na profundidade $0,05-0,10$ e 0,10-0,20 m. Os atributos diâmetro médio ponderado e classes de agregados maior que 2,00 mm apresentam correlação espacial negativa com carbono orgânico na profundidade $0,0-0,05$ m, enquanto a classes de agregados menor que $2,00 \mathrm{~mm}$ e densidade do solo apresentam correlação positiva com carbono orgânico nas profundidades $0,0-0,05 \mathrm{~m} \mathrm{e} \mathrm{0,10-0,20} \mathrm{m.}$

PALAVRAS-CHAVE: Agregação do solo. Geoestatística. Variograma cruzado.

\section{REFERENCES}

ALHO, L. C.; CAMPOS, M. C. C.; SILVA, D. M. P.; MANTOVANELLI, B. C.; SOUZA, Z. M. Variabilidade espacial da estabilidade de agregados e estoque de carbono em Cambissolo e Argissolo. Pesquisa

Agropecuária Tropical, Goiânia, v. 44, n. 3, p. 246-254, 2014. https://doi.org/10.1590/S1983-

40632014000300001

AQUINO, R. E.; CAMPOS, M. C. C.; MARQUES JUNIOR, J.; OLIVEIRA, I. A.; MANTOVANELI, B. C.; SOARES, M. D. R. Geoestatística na avaliação dos atributos físicos em Latossolo sob floresta nativa e pastagem na Região de Manicoré, Amazonas. Revista Brasileira de Ciência do Solo, Viçosa, v. 38, n. 2, p. 397-406, 2014.

AQUINO, R. E.; CAMPOS, M. C. C.; MARQUES JUNIOR, J.; OLIVEIRA, I. A.; TEIXEIRA, D. D. B.; CUNHA, J. M. Use of scaled semivariograms in the planning sample of soil physical properties in Southern Amazonas, Brazil. Revista Brasileira de Ciência do Solo, Viçosa, v. 39, n. 1, p. 21-30, 2015.

BRADY, N. C.; WEIL, R. R. The nature and properties of soils. 14. ed. New Jersey: Prentice Hall, 2008. 992 p.

BRASIL. Ministério das Minas e Energia. Projeto Radambrasil. 17. ed. Rio de Janeiro: Brazil, 1978. 566 p. 
BHATTI, A .U.; MULLA, D .J.; KOEHLER, F. E.; GURMANI, A. H. Identifying and removing spatial correlation from yield experiments. Soil Science Society of America Journal, Madison, v. 55, n. 6, p. 15231528, 1991.

CAJAZEIRA, J. P.; ASSIS JÚNIOR, R. N. Variabilidade espacial das frações primárias e agregados de um Argissolo no Estado do Ceará. Revista Ciência Agronômica, Fortaleza, v. 42, n. 2, p. 258-267, 2011. https://doi.org/10.1590/S1806-66902011000200002

CAMARGO, L. A.; MARQUES JÚNIOR, J.; PEREIRA, G. T.; HORVAT, R. A. Variabilidade espacial de atributos mineralógicos de um Latossolo sob diferentes formas do relevo. I - Mineralogia da fração argila. Revista Brasileira de Ciência do Solo, Viçosa, v. 32, n. 6, p. 2269-2277, 2008.

CAMBARDELLA, C. A.; MOORMAN, T. B.; NOVAK, J.; KONOPKA, A. E. Field scale variability of soil properties in central Iowa soil. Soil Science Society of America Journal, Madison, v. 58, n. 5, p. 1501-1511, 1994.

CAMPINAS, D. S. N.; FARIAS, P. R. S.; LIMA, H. V.; OLIVEIRA, F. J. Variabilidade espacial dos atributos físicos de solos em dois sistemas de manejo na Amazônia Oriental. Revista Científica Eletrônica de Agronomia, Garça, v. 24, n. 2, p. 78-87, 2013.

CARVALHO, L. C. C.; SILVA, F. M.; FERRAZ, G. A. S.; SILVA, F. C.; STRACIERI, J. Variabilidade espacial de atributos físicos do solo e características agronômicas da cultura do café. Coffee Science, Lavras, v. 8, n. 3, p. 265-275, 2013.

CARVALHO, L. A.; MEURER, I.; SILVA JÚNIOR, C. A.; CAVALIERI, K. M. V.; SANTOS, C. F. B. Dependência espacial dos atributos físicos de três classes de solos cultivados com cana-de-açúcar sob colheita mecanizada. Revista Brasileira de Engenharia Agrícola e Ambiental, Campina Grande, v. 15, n. 9, p. 940949, 2011. https://doi.org/10.1590/S1415-43662011000900010

CARVALHO, L. M.; CORREIA, P. M.; RYEL, R. J.; MARTINS-LOUÇÃO, M. A. Spatial variability of arbuscular mycorrhizal fungal spores in two natural plant communities. Plant and Soil, Dordrecht, v. 251, n. 2, p. 227-236, 2003. https://doi.org/10.1023/A:1023016317269

CORADO NETO, F. C.; SAMPAIO, F. M. T.; VELOSO, M. E. C.; MATIAS, S. S. R.; ANDRADE, F. R.; LOBATO, M. G. R. Variabilidade espacial dos agregados e carbono orgânico total em Neossolo Litólico Eutrófico no município de Gilbués, PI. Revista de Ciências Agrárias, Recife, v. 58, n. 1, p. 75-83, 2015.

CORÁ, J. E.; ARAUJO, A. V.; PEREIRA, G. T.; BERALDO, J. M. G. Variabilidade espacial de atributos do solo para adoção do sistema de agricultura de precisão na cultura de cana-de-açúcar. Revista Brasileira de Ciência do Solo, Viçosa, v. 28, n. 6, p. 1013-1021, 2004.

CUNHA, J. M.; CAMPOS, M. C. C.; GAIO, D. C.; SOUZA, Z. M.; SOARES, M. D. R.; SILVA, D. M. P.;SIMÕES, E. L. Spatial variability of soil respiration in Archaeological Dark Earth areas in the Amazon. Catena, Cremlingen, v. 162, p. 148-156, 2018.

DEUTSCH, C. V.; JOURNEL, A. G. GSLIB: geostatistical software library and user's guide. 2nd ed. New York: Oxford University, 1998. 369p.

EMBRAPA. Empresa Brasileira de Pesquisa Agropecuária - Centro Nacional de Pesquisa de Solos. Sistema brasileiro de classificação de solo. 3. ed. Rio de Janeiro: Embrapa, 2013. 353 p.

EMBRAPA. Empresa Brasileira de Pesquisa Agropecuária - Centro Nacional de Pesquisas de Solos. Manual de métodos de análises de solos. 2. ed. Rio de Janeiro: Embrapa Solos, 2011. 230p. 
GOMES, R. P.; CAMPOS, M. C. C.; SOARES, M. D. R.; SILVA, D. M. P.; CUNHA, J. M.; FRANCISCON, U.; SILVA, L. S.; OLIVEIRA, I. A; BRITO, W. B. M. variabilidade espacial de agregados e carbono orgânico sob três diferentes usos de terra preta de índio no sul do Amazonas. Bioscience Journal, Uberlândia, v. 33, n. 6, p. 1513-1522, 2017. https://doi.org/10.14393/BJ-v33n6a2017-37142

GUIMARÃES, P. T. G.; LOPES, A. S. Solos para cafeeiro: características, propriedades e manejo. In: RENA, A. B. (Ed.). Cultura do cafeeiro: fatores que afetam a produtividade. Piracicaba: Associação Brasileira para Pesquisa da Potassa e do Fosfato, 1986. p. 115-161.

HOLMES, K. W.; KYRIAKIDIS, P. C.; CHADWICK, O. A.; SOARES, J. V.; ROBERTS, D.A. Multi-scale variability in tropical soil nutrients following land-cover change. Biogeochemistry, The Netherlands, v. 74, p. 173-203, 2005. https://doi.org/10.1007/s10533-004-3544-x

ISAAKS, E. H.; SRIVASTAVA, R. M. An introduction to applied geoestatistics. New York, Oxford University Press, 1989. 561p.

KEMPER, W. D.; CHEPIL, W. S. Aggregate stability and size distribution. In: BLACK, C. A. (Ed.). Methods of soil analysis. Madison: American Society of Agronomy, 1965. p. 499-510.

LIMA, J. M.; ANDERSON, S. J. Aggregation and aggregate size effects on extractable iron and aluminum in two Hapludox. Soil Science Society of America Journal, Madison, v. 61, p. 965-970, 1997.

MARQUES JÚNIOR, J.; SOUZA, Z. M.; PEREIRA, G. T.; BARBIER, D. M. Variabilidade espacial de matéria orgânica, P, K e CTC de um Latossolo cultivado. Revista de Biologia e Ciências da Terra, São Cristóvão, v. 8, n. 1, p. 143-152, 2008.

MATHERON, G. Principles of geostatistics. Economic Geology, v. 58, p. 1246-66, 1963. https://doi.org/10.2113/gsecongeo.58.8.1246

MATIAS, S. S. R.; MARQUES JÚNIOR, J.; SIQUEIRA, D. S.; PEREIRA, G. T. Modelos de paisagem e susceptibilidade magnética na identificação e caracterização do solo. Pesquisa Agropecuária Brasileira, Brasília, v. 43, n. 1, p. 93-103, 2013. https://doi.org/10.1590/S1983-40632013000100003

McBRATNEY, A. B.; WEBSTER, R. Spatial dependence and classification of the soil along a transect in northeast Scotland. Geoderma, Amsterdam, v. 26, p. 63-82, 1981. https://doi.org/10.1016/0016-

7061(81)90076-8

MINITAB RELEASE 14.1. Statistical Software. US/Canadá, 2000.

MOTA JR, P.C.; CAMPOS, M.C.C.; MANTOVANELLI, B.C.; FRANCISCON, U.; CUNHA, J.M. Variabilidade espacial de atributos físicos do solo em Terra Preta de Índio sob cultivo de café conilon. Coffee Science, Lavras, v. 12, n. 2, p. 260-271, 2017.

MOTA, J. C. A.; FREIRE, A. G.; ASSIS JÚNIOR, R. N. Qualidade física de um Cambissolo sob sistemas de manejo. Revista Brasileira de Ciências do Solo, Viçosa, v. 37, n. 5, p. 1196-1206, 2013.

OLIVEIRA, I. A.; CAMPOS, M. C. C.; SOARES, M. D. R.; AQUINO, R. E.; MARQUES JÚNIOR, J.; NASCIMENTO, E. P. Variabilidade espacial de atributos físicos em um Cambissolo Háplico, sob diferentes usos na região Sul do Amazonas. Revista Brasileira de Ciências do Solo, Viçosa, v. 37, n. 4, p. 1103-1112, 2013.

OLIVEIRA, I. A.; MARQUES JÚNIOR, J.; CAMPOS, M. C. C.; AQUINO, R. E.; FREITAS, L.; SIQUEIRA, D. S.; CUNHA, J. M. Variabilidade espacial e densidade amostral da suscetibilidade magnética e dos atributos de Argissolos da região de Manicoré, AM. Revista Brasileira de Ciências do Solo, Viçosa, v. 39, n. 3, p. 668$681,2015$. 
PASSOS, R. R.; RUIZ, H. A.; MENDONÇA, E. S.; CANTARUTTI, R. B.; SOUZA, A. P. Substâncias húmicas, atividade microbiana e carbono orgânico lábil em agregados de um Latossolo vermelho distrófico sob duas coberturas vegetais. Revista Brasileira de Ciências do Solo, Viçosa, v. 31, v. 5, p. 1119-1129, 2007.

ROBERTSON, G. P. GS+: Geostatistics for the environmental sciences - GS+ User's. Guide. Plainwell, Gamma Design Software, 1998, 152pp.

SCHAFFRATH, V. R.; TORMENA, C. A.; FIDALSKI, J.; GONÇALVES, A. C. A. Variabilidade e correlação espacial de algumas propriedades físicas de um Latossolo Vermelho distroférrico sob plantio direto e preparo convencional. Revista Brasileira de Ciência do Solo, Viçosa, v. 32, n. 4, p. 1411-1417, 2008.

SILVA, D. M. P.; CAMPOS, M. C. C.; FRANCISCON, U.; ALHO, L. C.; SANTOS, L. A. C.; PAULA NETO, P.; BERGAMIN, A. C.; SOUZA, Z. M. Variabilidade espacial das propriedades do solo em sítio de terra preta arqueológica sob cultivo de cacau. Revista Brasileira de Ciência do Solo, Viçosa, v. 40, n. (e0140816), p. 1-12, 2016.

SIQUEIRA, D. S.; MARQUES JÚNIOR, J.; PEREIRA, G. T. The use of landforms to predict the variability of soil and orange attributes. Geoderma, Amsterdam, v. 155, n. 3-4, p. 55-66, 2010.

SOARES, M. D. R.; CAMPOS, M. C. C.; SOUZA, Z. M.; BRITO, W. B. M.; FRANCISCON, U.;

CASTIONE, G. A. F. Variabilidade espacial dos atributos físicos do solo em área de Terra Preta Arqueológica sob pastagem em Manicoré, AM. Revista de Ciências Agrárias, Recife, v. 58, v. 4, p. 434-441, 2015. https://doi.org/10.1016/j.geoderma.2009.11.024

SOIL SURVEY STAFF. Keys to soil taxonomy. 12. ed. Washington: Department of Agriculture, Natural Resources Conservation Service, 2014. 372 p.

SOUZA, Z. M.; MARQUES JÚNIOR, J.; PEREIRA, G. T. Spatial variability of the physical and mineralogical properties of the soil from the areas with variation in landscape shapes. Brazilian Archives of Biology and Technology, Curitiba, v. 52, n. 2, p. 305-316, 2009. https://doi.org/10.1590/S1516-89132009000200007

SURFER FOR WINDOWS. REALESE 7.0. Contouring and 3D surface mapping for scientist's engineers: User's guide. New York: Golden Software, 1999. 619 p.

TAVARES, U. E.; ROLIM, M. M.; PEDROSA, E. M. R.; MONTENEGRO, A. A. A.; MAGALHÃES, A. G.; BARRETO, M. T. L. Variabilidade espacial de atributos físicos e mecânicos de um Argissolo sob cultivo de cana-de-açúcar. Revista Brasileira de Engenharia Agrícola e Ambiental, Campina Grande, v. 16, n. 11, p. 1206-1214, 2012. https://doi.org/10.1590/S1415-43662012001100009

VASCONCELOS, R. F. B.; SOUZA, E. R. S.; CANTALICE, J. R. B.; SILVA, L. S. Qualidade física de Latossolo Amarelo de tabuleiros costeiros em diferentes sistemas de manejo da cana-de-açúcar. Revista Brasileira de Engenharia Agrícola e Ambiental, Campina Grande, v. 18, n. 4, p. 381-386, 2014. https://doi.org/10.1590/S1415-43662014000400004

VIEIRA, S. R.; HATFIELD, J. L.; NIELSEN, D. R.; BIGGAR, J. W. Geoestatiscal theory and application to variability of some agronomical properties. Hilgardia, Riverside, v. 51, n. 3, p. 1-75, 1983.

https://doi.org/10.3733/hilg.v51n03p075

WARRICK, A. W.; NIELSEN, D. R. Spatial variability of same physical properties of the soil. In: HILL, D. (Ed.). Applications of soil physics. New York: Academic, 1980. p. 319-344. https://doi.org/10.1016/B978-012-348580-9.50018-3

YEOMANS, J. C.; BREMNER, J. M. A rapid and precise method for routine determination of organic carbon in soil. Journal Communications in Soil Science and Plant Analysis, New York, v. 19, n. 13, p. 1467-1476, 1988. https://doi.org/10.1080/00103628809368027 